\title{
Effects of ACE polymorphisms and other risk factors on the severity of coronary artery disease
}

\author{
A.I. Guney ${ }^{1}$, D. Ergec', D. Kirac ${ }^{2}$, H. Ozturhan ${ }^{3}$, M. Caner ${ }^{4}$, G. Koc ${ }^{1}$, \\ C. Kaspar ${ }^{5}$, K. Ulucan ${ }^{6}$ and M. Agirbasli ${ }^{3}$ \\ ${ }^{1}$ Department of Medical Genetics, Faculty of Medicine, Marmara University, \\ Istanbul, Turkey \\ ${ }^{2}$ Department of Medical Biology, Faculty of Medicine, Yeditepe University, \\ Istanbul, Turkey \\ ${ }^{3}$ Department of Cardiology, Faculty of Medicine, Marmara University, \\ Istanbul, Turkey \\ ${ }^{4}$ Department of Medical Biology, Faculty of Medicine, Maltepe University, \\ Istanbul, Turkey \\ ${ }^{5}$ Department of Biostatistics, Faculty of Medicine, Yeditepe University, \\ Istanbul, Turkey \\ ${ }^{6}$ Department of Molecular Biology and Genetics, \\ Faculty of Engineering and Natural Sciences, Üsküdar University, Istanbul, Turkey \\ Corresponding author: K. Ulucan \\ E-mail: korkutulucan@hotmail.com
}

Genet. Mol. Res. 12 (4): 6895-6906 (2013)

Received February 20, 2013

Accepted September 19, 2013

Published December 19, 2013

DOI http://dx.doi.org/10.4238/2013.December.19.8

\begin{abstract}
Coronary artery disease (CAD) is a multifactorial disease influenced by genetic and environmental factors. Major risk factors of CAD are hypertension, hyperlipidemia, smoking, family history and obesity. Also polymorphisms in the angiotensin-I converting enzyme $(A C E)$ gene can associate with CAD. The relationship between ACE polymorphisms and other risk factors is not well understood in CAD, likely due to the complex interrelation of genetic and environmental risk factors. The aim of this study was to investigate the associations of CAD risk factors and $A C E$ polymorphisms in patients with CAD. We enrolled 203 consecutive
\end{abstract}


patients and 140 healthy subjects in the study. The severity of CAD was evaluated according to the number of vessels with significant stenosis. $A C E$ insertion (I)/deletion (D) genotype was determined by PCR. The frequency of the DD genotype was significantly higher in patients. D allele frequency was higher among CAD subjects when compared to the control group. The number of stenotic vessels were found to be statistically associated with a high frequency of DD polymorphism and D allele and a low frequency of I allele in patients, especially in male patients. The control group displayed II and ID genotypes more frequently than did the patients. The $A C E \mathrm{I} / \mathrm{D}$ genotype was associated with hyperlipidemia and smoking history. We consider that the DD polymorphism and D allele may affect the severity of CAD, while I allele may have a protective effect. In conclusion, the $A C E \mathrm{I} / \mathrm{D}$ genotype may interact with conventional risk criteria in determining the risk of CAD.

Key words: Multifactorial disease; Hyperlipidemia; Obesity; Smoking; Angiotensin-I coverting enzyme

\section{INTRODUCTION}

Coronary artery disease (CAD) is the most prevalent cause of morbidity and mortality worldwide. It is a multifactorial disease, which is influenced by genetic and environmental factors (Settin et al., 2009). The major risk factors of CAD are age, male gender, hypertension, diabetes mellitus, hyperlipidemia, smoking, family history of CAD and obesity. In addition to standard risk criteria, genetic factors add further information in predicting CAD (Erbs et al., 2006). The relationship between genetic risk factors and the development of CAD is not well understood, likely due to the complex interrelation of genetic and environmental risk factors. Recent evidence indicates that major cardiovascular risk factors influence renin-angiotensin system (RAS) function, including an increased synthesis of the angiotensin-I converting enzyme (ACE) (Li et al., 2003). RAS is one of the major regulatory systems of the cardiovascular physiology. It includes cardiovascular remodeling, sodium homeostasis, and maintenance of vascular tone (Pfohl et al., 1999). RAS play an important role in cell growth and in the repair of damaged arterial walls; thus it was suggested that $A C E$ might be a candidate gene affecting the progression of CAD. Elevated levels of ACE expedite the conversion of angiotensin I to angiotensin II. Then, aldosterone is released from the adrenal cortex to stimulate the kidney tubules and initiate the reabsorption of sodium and water from urine. To compensate for volume loss, angiotensin II stimulates an increase in the amount of fluids in the blood, thus increasing blood pressure. In addition, angiotensin II may play a role in inducing endothelial dysfunction by reducing the bioavailability of nitric oxide. ACE is also an important factor in the degradation of bradykinin (Sayed-Tabatabaei et al., 2006).

The $A C E$ gene is located on chromosome $17 \mathrm{q} 23$. It spans $21 \mathrm{~kb}$, and comprises 26 exons and 25 introns (Hubert et al., 1991). It contains a polymorphism due to an insertion (I) or a deletion (D) of a 287 base pair (bp) alu sequence in intron 16, resulting in the 3 genotypes of insertion/insertion (II), insertion/deletion (ID), and deletion/deletion (DD). (Hubert et al., 1991; Rigat et al., 1992; Nacak et al., 2004). The I/D polymorphism is associated with circulating and 
tissue ACE levels. Individuals homozygous for the D allele had higher tissue and plasma ACE concentrations than heterozygotes and II homozygotes (Costerousse et.al., 1993). ACE polymorphism has attracted a great deal of information as a potential cause of genetic variation in cardiovascular physiological function (Eleni et al., 2008). Consequently, the $A C E \mathrm{I} / \mathrm{D}$ polymorphism has been associated with various cardiovascular diseases, such as atherosclerosis (Pfohl, et al., 1998), hypertension (Abbud et al., 1998), and CAD (Gardemann et al., 1998). ACE, as a candidate gene, can associate with traditional risk factors in predicting the severity of CAD.

\section{MATERIAL AND METHODS}

\section{Study population}

Patients were selected consecutively from a tertiary care hospital from 2007-2009. Subjects were referred for coronary angiography as a result of various clinical indications. Physical examination was performed on and a detailed family history was obtained for all subjects. The severity of CAD was evaluated according to the number of stenotic vessels on coronary angiography. The coronary angiography findings were reviewed by independent operators. The experimental protocol was approved by the Ethical Committee of the Marmara University, the study procedures were in accordance with the principles of the Declaration of Helsinki II, and all subjects provided written informed consent prior to enrollment.

Information about the conventional risk factors for $\mathrm{CAD}$ (1. hyperlipidemia, 2. hypertension, 3. diabetes mellitus, 4. family history of CAD, 5. smoking, 6. obesity) were obtained from all subjects. Definitions of cardiovascular risk factors were adopted from Graham et al. (2007). Hyperlipidemia is defined based on low ( $>100 \mathrm{mg} / \mathrm{dL}$ for subjects with CAD) and/or high-density lipoprotein cholesterol ( $<40 \mathrm{mg} / \mathrm{dL}$ for men and $<50 \mathrm{mg} / \mathrm{dL}$ for women) and triglyceride levels $(>150 \mathrm{mg} / \mathrm{dL})$, or prior requirement of lipid lowering medications. As our study included patients with clinically established atherosclerosis and they were all referred to coronary angiography for clinical indications, total cholesterol $>200 \mathrm{mg} / \mathrm{dL}$, low density lipoprotein cholesterol $\geq 100 \mathrm{mg} /$ $\mathrm{dL}$, triglycerides $>150 \mathrm{mg} / \mathrm{dL}$, and low high density lipoprotein cholesterol $(<40 \mathrm{mg} / \mathrm{dL}$ for men and $<50 \mathrm{mg} / \mathrm{dL}$ for women) were defined as components of hyperlipidemia.

Hypertension is defined as blood pressure level above 140/90 on 3 different occasions or requirement of pharmacological intervention to lower blood pressure. Diabetes mellitus is defined as fasting venous blood glucose $\geq 126 \mathrm{mg} / \mathrm{dL}$ on 3 separate occasions or requirement of pharmacological intervention for diabetes mellitus. Family history of CAD was defined as having a first degree relative with established CAD before age 50, or before menopause. Cigarette smoking was assessed by asking participants about prior and current history of smoking habits. Body mass index (BMI) was calculated as weight $(\mathrm{kg}) /$ height $\left(\mathrm{m}^{2}\right)$. Overweight or obesity were defined based on the BMI levels ( $>25-29.9$ and $\geq 30 \mathrm{~kg} / \mathrm{m}^{2}$ respectively), as outlined in Graham et al. (2007) and Expert Panel on Detection, Evaluation and Treatment of High Blood Cholesterol in Adults (2001). CAD was defined as a documented coronary obstruction of at least $70 \%$ by quantitative coronary angiography in one or more major (more than 2 $\mathrm{mm}$ in diameter by quantitative coronary angiography) coronary arteries. Enrolled cases were stratified into groups according to the number of diseased vessels (coronary obstruction of at least $70 \%$ ) as determined by the number of diseased major coronary arteries (left anterior descending, left circumflex, and right coronary artery) including their major branches (more 
than $2 \mathrm{~mm}$ in diameter). Patients were grouped into $0,1,2,3$, or 4 vessel disease groups. Patients without significant coronary obstruction by coronary angiography (less than $30 \%$ ) were selected as controls.

\section{$A C E$ genotyping}

Genomic DNAs of 203 cases and 140 controls were isolated from peripheral blood leukocytes using the High Pure PCR Template Preparation Kit (Roche, Germany) according to manufacturer protocol and stored at $-20^{\circ} \mathrm{C}$ until amplification.

$A C E$ genotypes were determined by PCR amplification of genomic DNA with sense primer 5'-CTGGAGACCACTCCCATCCTTTCT-3' and antisense primer 5'-GATGTGGCCA TCACATTCGTCAGT-3'. The final volume of the PCR mixture was $50 \mu \mathrm{L}$ and contained 50 $100 \mathrm{ng}$ genomic DNA, $1 \mathrm{mM}$ of each primer, $50 \mathrm{mM} \mathrm{KCl}, 1 \mathrm{mM}$ dNTP, $1.5 \mathrm{mM} \mathrm{MgCl}, 10$ $\mathrm{mM}$ Tris- $\mathrm{HCl}, \mathrm{pH} 8.0$, and $1 \mathrm{U}$ Taq DNA polymerase. After initial denaturation at $94^{\circ} \mathrm{C}$ for 5 min, annealing at $58^{\circ} \mathrm{C}$ for $1 \mathrm{~min}$, and extension at $72^{\circ} \mathrm{C}$ for $2 \mathrm{~min}$, DNA was amplified by 30 cycles: denaturation at $94^{\circ} \mathrm{C}$ for $1 \mathrm{~min}$, annealing at $58^{\circ} \mathrm{C}$ for $1 \mathrm{~min}$, and extension at $72^{\circ} \mathrm{C}$ for $2 \mathrm{~min}$, followed by a final elongation at $94^{\circ} \mathrm{C}$ for $1 \mathrm{~min}$, annealing at $58^{\circ} \mathrm{C}$ for $1 \mathrm{~min}$, and extension at $72^{\circ} \mathrm{C}$ for $7 \mathrm{~min}$. PCR products were separated by electrophoresis on a $2 \%$ agarose gel and visualized under ultraviolet light after ethidium bromide staining. The PCR product is a 190-bp fragment in the presence of a deletion (D) allele, and a 490-bp fragment in the absence of a deletion (I) allele. So after electrophoresis, each DNA sample revealed one of three possible patterns: a 490-bp band (II genotype), a 190-bp band (DD genotype), or both 490- and 190-bp bands (I/D genotype).

\section{Statistical analysis}

Statistical analysis was performed using SPSS-18.0 (Statistical Package of Social Science version 18.0). Allele frequencies were deduced from genotype frequencies. The differences in allele and genotype frequencies between the groups were evaluated by chi-square test. This test was also used to compare categorical variables between the groups (i.e. conventional CAD risk factors). The relationship between the severity of the disease (according to the number of diseased vessels) and genotype distributions were first tested by the Kruskal-Wallis test. Then, the Mann-Whitney U-test was used for significant parameters to determine which one of the genotypes causes this significance. In addition, odd ratios were calculated to show the effect of the risk factor for all statistically significant parameters.

\section{RESULTS}

Two hundred and three consecutive patients (ages 51.9 \pm 12.6 for women and $54.1 \pm 9.2$ for men) were enrolled in the study after the coronary angiography findings were reviewed. All subjects had severe $\mathrm{CAD}(>70 \%)$ in at least 1 major coronary artery. The control group consisted of 140 individuals who had no significant coronary obstruction by coronary angiography (ages $42.3 \pm 13.1$ for men, $49.5 \pm 8.5$ for women). The indications for coronary angiography included acute coronary syndromes (i.e. acute myocardial infarction, unstable angina) and/or positive functional study (i.e. exercise treadmill or myocardial perfusion scintigraphy). 
Conventional cardiovascular risk criteria (hyperlipidemia, obesity, diabetes mellitus, smoking and male gender) were observed more commonly among CAD subjects than in the control group. Information about the prevalence of conventional CAD risk factors in the patient and control groups is listed in Table 1.

Table 1. Prevalence of conventional coronary artery disease (CAD) risk factors in patients and controls.

\begin{tabular}{|c|c|c|c|}
\hline \multirow[t]{2}{*}{ Risk factors } & \multicolumn{2}{|c|}{ Frequencies (\%) } & \multirow[t]{2}{*}{$P$ values } \\
\hline & Patient group $(\mathrm{N}=203)$ & Control group $(\mathrm{N}=140)$ & \\
\hline Dyslipidemia & $90(43.9 \%)$ & $33(23.6 \%)$ & $0.000 *$ \\
\hline Hypertension & $99(48.3 \%)$ & $67(47.9 \%)$ & 0.913 \\
\hline Diabetes mellitus & $51(24.9 \%)$ & $18(12.9 \%)$ & $0.006^{*}$ \\
\hline Family history & $77(37.6 \%)$ & $47(33.6 \%)$ & 0.426 \\
\hline Smoking & $90(43.9 \%)$ & $40(28.6 \%)$ & $0.003 *$ \\
\hline \multicolumn{4}{|l|}{ Gender } \\
\hline Females & $68(33.2 \%)$ & $62(44.3 \%)$ & $0.000 *$ \\
\hline Males & $137(66.8 \%)$ & $78(55.7 \%)$ & \\
\hline Obesity & $16(7.8 \%)$ & $0(0 \%)$ & $0.000 *$ \\
\hline
\end{tabular}

$* \mathrm{P}<0.05, \mathrm{P}$ values based on chi-square test.

Agarose gel images of $A C E$ polymorphisms are shown in Figure 1. When patient and control group genotypes were compared with each other, the DD genotype frequency was found to be statistically higher in patients than in controls. Also the II and ID polymorphisms were observed to be statistically lower in controls than in patients $(\mathrm{P}=0.036, \mathrm{OR}: 1.8,95 \% \mathrm{CI}$ $=1.14-2.8)$. The genotype frequencies of the patient and control groups are reported in Table 2 .

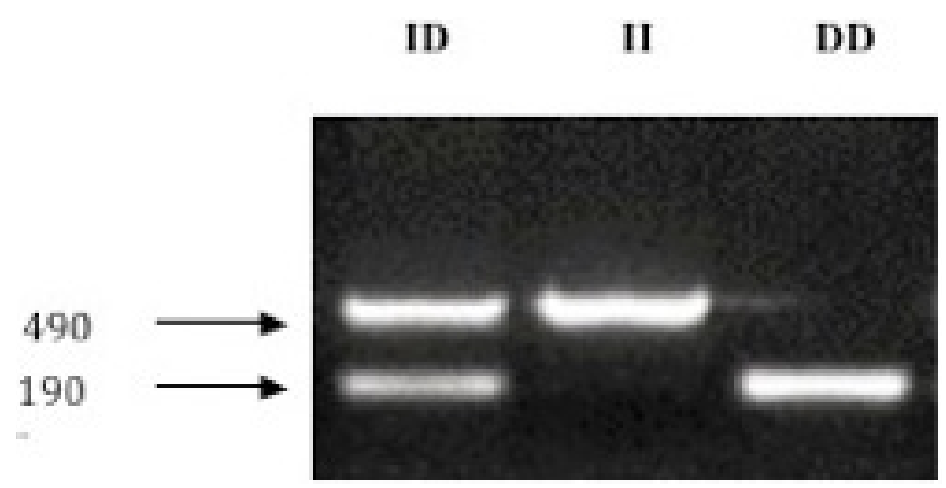

Figure 1. Agarose gel images of ACE polymorphisms.

Table 2. Genotype frequencies of patient and control groups.
\begin{tabular}{lcccc}
\hline Groups & \multicolumn{3}{c}{ Genotype frequencies (\%) } & P value \\
\cline { 2 - 4 } & II & ID & DD & $0.036^{*}$ \\
\hline Patient group ( $\mathrm{N}=203)$ & $38(18.5 \%)$ & $81(39.5 \%)$ & $86(42 \%)$ & $40(28.6 \%)$ \\
Control group $(\mathrm{N}=140)$ & $35(25 \%)$ & $65(46.4 \%)$ & $40)$ \\
\hline
\end{tabular}

$* \mathrm{P}<0.05, \mathrm{P}$ values based on chi-square test 
We compared the patient and control group allele frequencies with each other and found that $\mathrm{D}$ allele frequency was statistically significantly higher in patients than in controls $(\mathrm{P}=0.02$, OR: $1.44,95 \% \mathrm{CI}=1.058-1.962)$. Allele frequencies of patient and control groups are shown in Table 3.

Table 3. Allele frequencies of patient and control groups.
\begin{tabular}{lrrr}
\hline Groups & \multicolumn{2}{c}{ Allele frequencies (\%) } & P value \\
\cline { 2 - 3 } & $\mathrm{I}$ & $\mathrm{D}$ & $0.02 *$ \\
\hline Patient group $(\mathrm{N}=203)$ & $157(39.3 \%)$ & $145(60.8 \%)$ & $0.8 \%)$ \\
Control group $(\mathrm{N}=140)$ & $135(48.2 \%)$ &
\end{tabular}

$* \mathrm{P}<0.05, \mathrm{P}$ values based on chi-square test.

ID polymorphism was found to be statistically significant in patients who have hyperlipidemia $(\mathrm{P}=0.009$, OR: $2.42,95 \% \mathrm{CI}=1.36-4.32)$ and smoking habits $(\mathrm{P}=0.004$, OR: $2.42,95 \% \mathrm{CI}=1.36-4.32$ ) when the genotype frequencies were compared with CAD risk factors. Genotype frequencies of patient and control groups according to different risk factors are shown in Table 4.

\begin{tabular}{|c|c|c|c|c|c|c|c|c|}
\hline \multirow[t]{3}{*}{ Risk factors } & \multirow{2}{*}{\multicolumn{3}{|c|}{$\begin{array}{c}\text { Patients }(\mathrm{N}=203) \\
\text { Genotype frequencies }(\%)\end{array}$}} & \multirow[t]{3}{*}{$P$ values } & \multirow{2}{*}{\multicolumn{3}{|c|}{$\begin{array}{c}\text { Controls }(\mathrm{N}=140) \\
\text { Genotype frequencies }(\%)\end{array}$}} & \multirow[t]{3}{*}{ P values } \\
\hline & & & & & & & & \\
\hline & II & ID & $\mathrm{DD}$ & & II & ID & $\mathrm{DD}$ & \\
\hline Hyperlipidemia & $13(14.4 \%)$ & $46(51.1 \%)$ & $31(34.4 \%)$ & $0.009^{*}$ & $4(12.1 \%)$ & $16(48.5 \%)$ & $13(39.4 \%)$ & 0.097 \\
\hline Hypertension & $19(19.2 \%)$ & $44(44.4 \%)$ & $36(36.4 \%)$ & 0.264 & $13(20 \%)$ & $34(52.3 \%)$ & $18(27.7 \%)$ & 0.607 \\
\hline Diabetes & $11(21.6 \%)$ & $20(39.2 \%)$ & $20(39.2 \%)$ & 0.814 & $2(11.1 \%)$ & $10(55.6 \%)$ & $6(33.3 \%)$ & 0.345 \\
\hline Family history & $12(15.6 \%)$ & $34(44.2 \%)$ & $31(40.3 \%)$ & 0.487 & $9(20 \%)$ & $21(46.7 \%)$ & $15(33.3 \%)$ & 0.821 \\
\hline Smoking & $10(11.1 \%)$ & $46(51.1 \%)$ & $34(37.8 \%)$ & $0.004 *$ & $11(27.5 \%)$ & $19(47.5 \%)$ & $10(25.0 \%)$ & 0.817 \\
\hline \multicolumn{9}{|l|}{ Gender } \\
\hline Females & $16(23.5 \%)$ & $23(33.8 \%)$ & $29(42.6 \%)$ & 0.331 & $12(20.7 \%)$ & $29(50 \%)$ & $17(29.3 \%)$ & 0.959 \\
\hline Males & $22(16.1 \%)$ & $58(42.3 \%)$ & $57(41.6 \%)$ & & $17(22.4 \%)$ & $36(47.4 \%)$ & $23(30.3 \%)$ & \\
\hline Obesity & $4(25 \%)$ & $9(56.3 \%)$ & $3(18.8 \%)$ & 0.341 & $0(0 \%)$ & $0(0 \%)$ & $0(0 \%)$ & - \\
\hline
\end{tabular}

$* \mathrm{P}<0.05, \mathrm{P}$ values based on chi-square test.

The number of diseased vessels was compared between genotypes in patients, and the DD genotype was associated with a higher number of diseased vessels when compared to the II genotype $(\mathrm{P}=0.011, \mathrm{OR}: 1.45,95 \% \mathrm{CI}=1.046-2.019)$. The mean values of the number of diseased vessels in patients are shown in Table 5.

\begin{tabular}{|c|c|c|c|c|}
\hline \multirow[t]{2}{*}{ Patients $(\mathrm{N}=203)$} & \multicolumn{3}{|c|}{ Mean values of number of diseased vessels \pm standard deviation } & \multirow[t]{2}{*}{$P$ value } \\
\hline & II & ID & DD & \\
\hline Whole patients & $1.86 \pm 0.99$ & $2.32 \pm 0.88$ & $2.46 \pm 0.82$ & $0.011 *$ \\
\hline Male patients & $1.71 \pm 0.96$ & $2.49 \pm 0.85$ & $2.67 \pm 0.7$ & $0.001 *$ \\
\hline Female patients & $2.07 \pm 1.03$ & $1.91 \pm 0.85$ & $2.07 \pm 0.9$ & 0.29 \\
\hline
\end{tabular}

$* \mathrm{P}<0.05$, $\mathrm{P}$ values based on Kruskal-Wallis test. 
When the number of diseased vessels were compared according to the allele frequencies, the $\mathrm{D}$ allele was associated with a higher number of diseased vessels than was the I allele $(\mathrm{P}=0.002$, OR: $1.96,95 \% \mathrm{CI}=1.28-2.98)$, and the I allele was found to be statistically low in patients $(\mathrm{P}=0.026$, OR: $0.69,95 \% \mathrm{CI}=0.49-0.96)$. The mean values of the number of diseased vessels in the I allele and the $\mathrm{D}$ allele were found to be $2.39 \pm 0.85(\mathrm{P}=0.043)$ and $2.17 \pm 0.94$ $(\mathrm{P}=0.005)$, respectively. The genotype distributions of patients according to the severity of disease (according to the number of stenotic vessels) are shown in Figure 2.

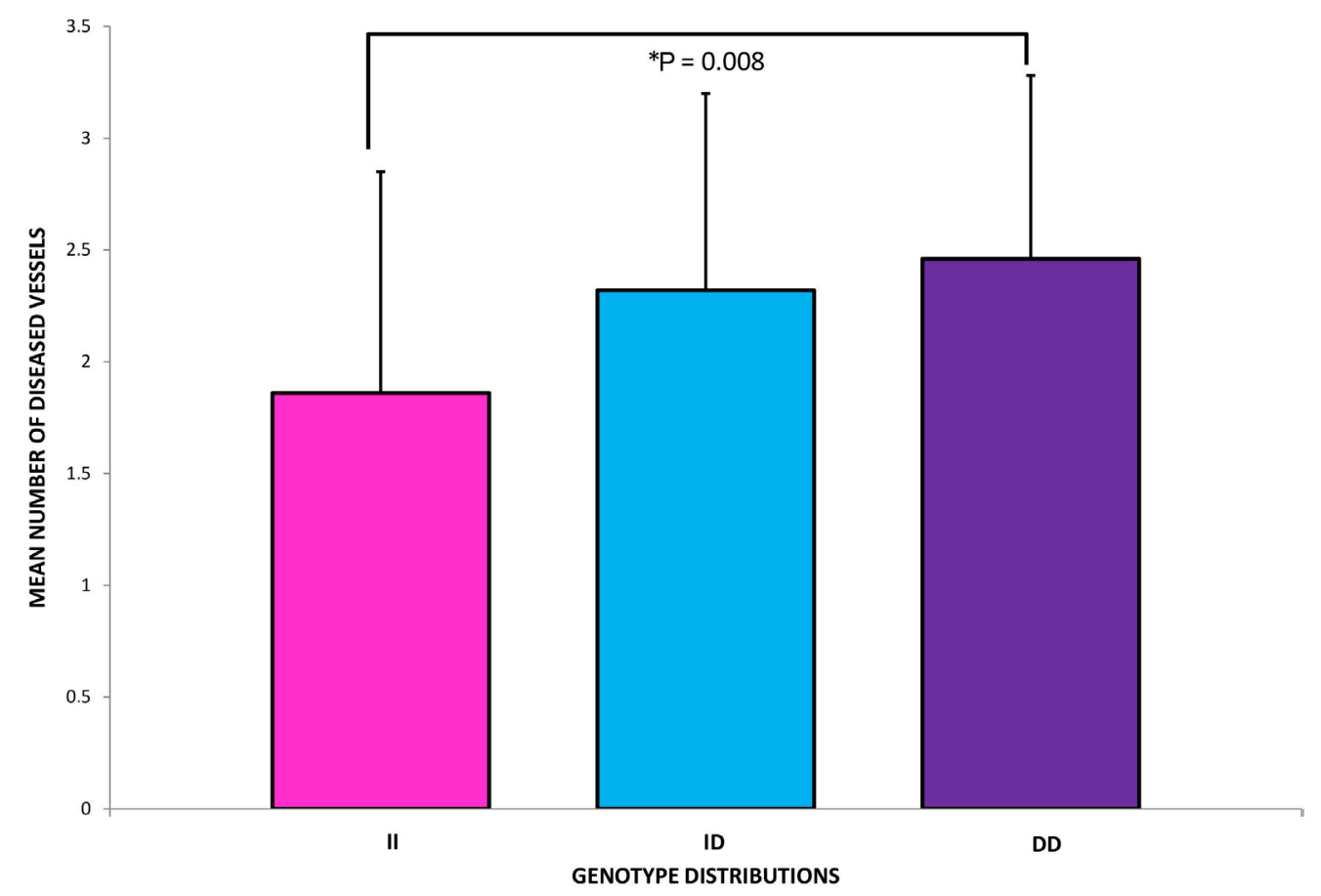

Figure 2. Genotype distributions of patients according to the severity of disease. ${ }^{*} \mathrm{P}<0.05$, $\mathrm{P}$ value based on MannWhitney U test.

When the number of diseased vessels was compared between genotypes in male patients, the DD and ID genotypes were associated with a statistically higher number of diseased vessels than the II genotype $(\mathrm{P}=0.001$, OR: $1.76,95 \% \mathrm{CI}=1.13-2.74)$. When the number of diseased vessels was compared according to the allele frequencies, the $\mathrm{D}$ allele was associated with a higher number of diseased vessels $(\mathrm{P}=0.000$, OR: $3.28,95 \% \mathrm{CI}=1.79-5.99)$ and the I allele was associated with a statistically lower number of diseased vessels in male patients ( $\mathrm{P}$ $=0.012$, OR: $0.57,95 \% \mathrm{CI}=0.36-0.88)$. The mean values of the number of diseased vessels in the $\mathrm{D}$ allele and the I allele were found to be $2.58 \pm 0.78(\mathrm{P}=0.000)$ and $2.27 \pm 0.94(\mathrm{P}=$ $0.019)$ respectively. The genotype distributions of male patients according to the severity of disease are reported in Figure 3. 


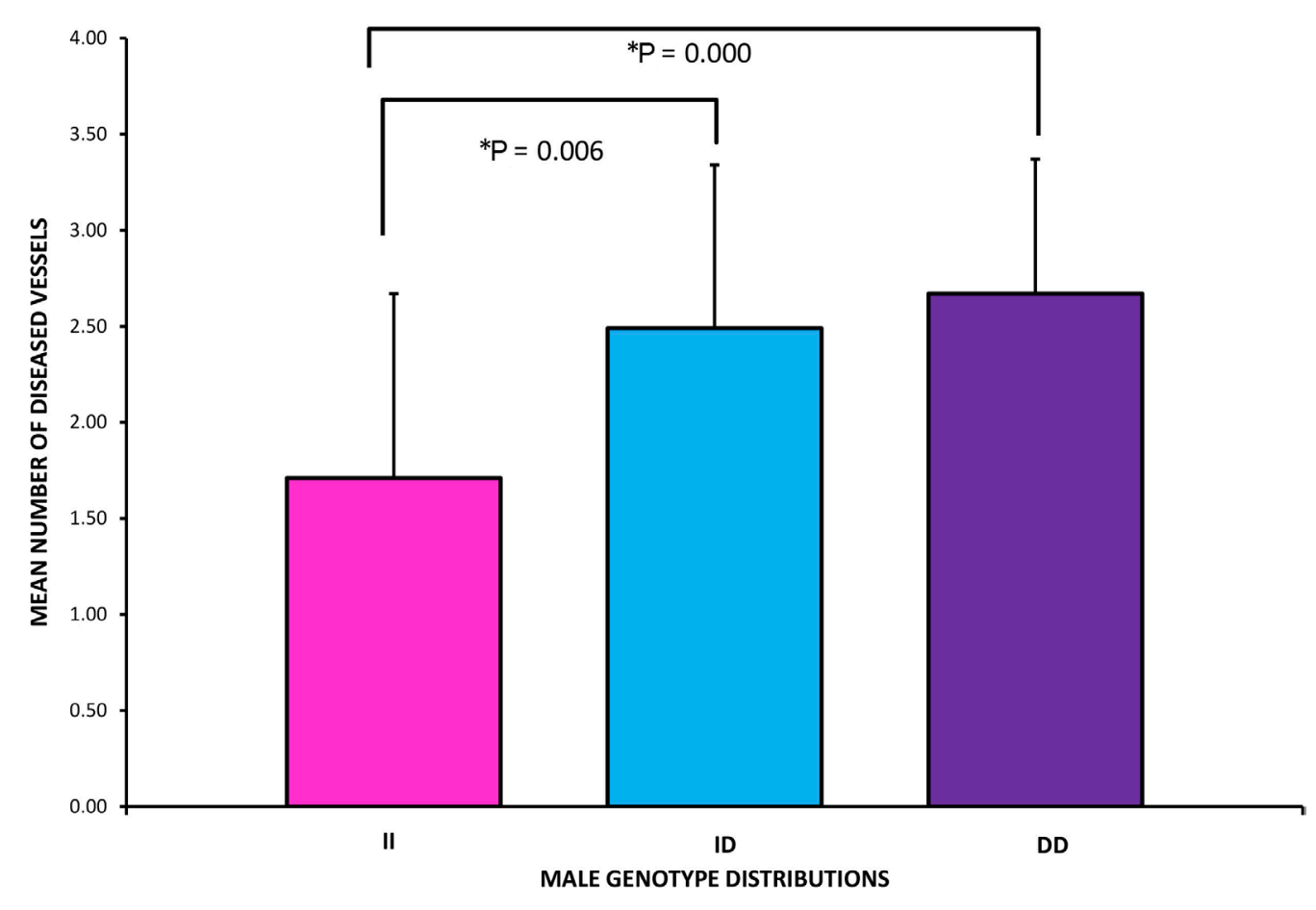

Figure 3. Genotype distributions of male patients according to the severity of disease. ${ }^{*} \mathrm{P}<0.05$, $\mathrm{P}$ values based on Mann-Whitney U test.

\section{DISCUSSION}

CAD is a polygenic disease. The onset and severity of CAD depends on the interaction of many genetic and environmental factors. A genetic variation in the gene encoding ACE affects circulating ACE levels. The DD, ID and II genotypes are associated with high, intermediate and low levels of circulating ACE, respectively (Cambien et al., 1994). Our study displays that the $A C E(\mathrm{I} / \mathrm{D})$ polymorphism interacts with standard CAD risk factors among male patients in determining the severity of the CAD. The relationship between CAD and $A C E$ gene polymorphism (DD genotype) was first reported by Cambien et al. (1994). Since then, many other studies have investigated the relationship between the $A C E \mathrm{I} / \mathrm{D}$ gene polymorphism and CAD. Although Gardemann et al. (1998) showed a strong association between the $A C E \mathrm{D}$ allele and the risk of CAD, other studies have failed to show a similar association (Ferrieres et al., 1999; Canavy et al., 2000). Carriers of the D allele of $A C E \mathrm{I} / \mathrm{D}$ polymorphism cause elevated serum and cardiac ACE activity and, therefore, may be exposed to higher angiotensin II levels than those with the I allele. Individuals who have the DD genotype are found to have high serum ACE levels. Association studies investigated the role of the $A C E \mathrm{I} / \mathrm{D}$ polymorphism and the D allele as a genetic predictor of CAD (Mattu et al., 1995; Istrati et al., 2006), myocardial infarction (Seckin et al., 2006), left ventricular hypertrophy (van Berlo and Pinto, 2003) and hypertension (Harrap et al., 1993). Beohar et al. (1995) considered that the $A C E \mathrm{D}$ allele and DD genotype were the major risk factors for CAD. Eth- 
nic differences can explain the disparity between prior clinical studies. Our results show that the $A C E \mathrm{D}$ allele frequency $(\mathrm{P}=0.02$, OR: $1.44,95 \% \mathrm{CI}=1.058-1.962)$ and $\mathrm{DD}$ genotype $(\mathrm{P}=$ 0.036 , OR: $1.8,95 \% \mathrm{CI}=1.14-2.8)$ are significantly more prevalent among $\mathrm{CAD}$ patients than in controls. Our findings are also consistent with previous studies. Niemiec et al. (2007) found that the frequency of the DD genotype was significantly higher in patients than in controls $(\mathrm{P}$ $=0.01$, OR: $1.88,95 \% \mathrm{CI}=1.13-3.15)$. Acartürk et al. (2005) found that in patients with $\mathrm{CAD}$, the frequency of the DD genotype was higher compared to the controls $(\mathrm{P}=0.04$, OR: 1.6, $95 \% \mathrm{CI}=1.0-2.5)$. The number of $\mathrm{D}$ allele-carrying subjects was also higher $(\mathrm{P}=0.01, \mathrm{OR}$ : $1.48,95 \% \mathrm{CI}=1.01-2.18)$ in $\mathrm{CAD}$ patients. In conclusion, they consider that the $\mathrm{I} / \mathrm{D}$ polymorphism of the $A C E$ gene (carrying D allele) is an independent risk factor for CAD in the studied Turkish population (Acartürk et al., 2005). Raygani et al. found that the frequency of the $A C E$ $\mathrm{D}$ allele was significantly higher in CAD patients than in controls; the percentage frequency of $A C E$ D allele in CAD subjects was 62.6 compared to 48.1 in controls (Vaisi-Raygani et al., 2010). The $\mathrm{D}$ allele frequencies reported in this study were similar to our findings. In our study, the percentage of $\mathrm{D}$ allele in the control group and the patient group were found to be 51.8 and 60.8 respectively. Raygani et al. also found that the $A C E \mathrm{D}$ allele increases the risk of CAD in individuals younger than 55 years old by 1.35-fold (Vaisi-Raygani et al., 2010). We found a 1.44-fold increase of $\mathrm{D}$ allele prevalence in patients who are younger than 55 years old. These results are also consistent with other studies performed in Spain (Alvarez et al., 1998) and Japan (Hoshida et al., 2001), demonstrating that the $A C E \mathrm{D}$ allele increases the risk for premature $\mathrm{CAD}$ in patients younger than 55 years old.

Although ACE levels are affected by the $A C E$ genotype, $A C E$ I/D polymorphism accounts for $20-50 \%$ of the difference in plasma ACE levels, therefore $50-80 \%$ of the variation results from other factors (Cambien et al., 1994). Traditional risk factors for CAD, like cigarette smoking, hyperlipidemia, hypertension, diabetes mellitus, family history of CAD, and obesity influence the RAS by increasing the synthesis of ACE. Higher levels of ACE increase vasoconstriction, which may result in an increased risk for CAD.

Hyperlipidemia, which is one of the major risk factors of CAD, increases the plasma concentration of angiotensinogen and the angiotensin peptides (angiotensins II and III), and upregulates the expression of the angiotensin II type 1 receptor $(A T 1 R)$ gene (Niemiec et al., 2007). Although the positive relationship between the DD genotype, the D allele frequency and hyperlipidemia was demonstrated by prior studies (Suzuki et al., 1996; Lee and Tsai, 2002). Many studies did not find an association among the three genotypes (II, ID, and DD) (Kogawa et al., 1997; Vargas-Alarcón et al., 2006). Oren et al. (1999) reported LDL cholesterol levels were lowest in II patients, intermediate in ID patients and higher in DD patients. The high frequency of the ID genotype in hyperlipidemic patients was demonstrated by Lee and Tsai et al. (2002). In our study, we observed a potential association between the ID genotype and hyperlipidemia $(\mathrm{P}=0.009$, OR: $2.42,95 \% \mathrm{CI}=1.36-4.32)$.

Cigarette smoking is another risk factor for CAD, and is particularly common in Turkish subjects. Previously, it was demonstrated that nicotine increased $A C E$ expression, resulting in an increase of the plasma and tissue activity of angiotensin (Zhang et al., 2001). The D allele has been associated with endothelial dysfunction, especially in smokers (Butler et al., 1999). Both smoking and the D allele have been associated with increased levels of angiotensin II, which have been shown to increase the formation of superoxide anions and the degradation of nitric oxide, causing endothelial dysfunction (Drexler and Hornig, 1999). As a result, it was considered 
that smoking impairs protective antioxidant mechanisms and changes the expression of $A C E$ (Zhang et al., 2001). In our study, patients of the ID genotype with a smoking history were found to have an increased risk of $\mathrm{CAD}(\mathrm{P}=0.004$, OR: $2.42,95 \% \mathrm{CI}=1.36-4.32)$. Therefore, there may be an association between the ID genotype, hyperlipidemia and cigarette smoking.

Previously, it was demonstrated that angiotensin II is produced primarily by ACE within atherosclerotic lesions, and that the $\mathrm{ACE}$ level in plaques correlates with the severity of vessel wall damage (Niemiec et al., 2008). Therefore, we also investigated the possible association of $A C E$ gene polymorphisms with the severity of CAD, estimated on the basis of the number of severe $(>70 \%)$ coronary stenoses by coronary angiography. We observed an association between the $\mathrm{D}$ allele and the severity of CAD among male patients. Although our results are consistent with previous studies (Nakai et al., 1994; Niemiec et al., 2008), there are studies that did not find any association between $A C E$ polymorphisms and the severity of CAD (Foy et al., 1997; Ferrieres, et al., 1999). Nakai et al. (1994) found that the DD polymorphism was more closely associated with CAD than the other two genotypes (ID and II) in patients. The frequency of $\mathrm{D}$ alleles was higher $(0.58)$ in the CAD group than in healthy control subjects $(0.42)(\mathrm{P}<0.05)$. Furthermore, multi-vessel disease was more strongly associated with $\mathrm{D}$ alleles than with I alleles $(\mathrm{P}<0.05)$ (Nakai et al., 1994). Niemiec et al. (2008) found that the frequencies of the DD genotype and the D allele increased with the number of stenoses in coronary vessels. Therefore, we consider that $A C E$ polymorphisms may influence individual differences in the severity of CAD; the $\mathrm{DD}$ genotype and $\mathrm{D}$ allele may promote the generation of numerous and critical atherosclerotic lesions. Therefore, the severity of CAD may be related to the DD genotype and the D allele of $A C E$ among patients and male patients. Further studies are needed to confirm our findings.

Further investigations are required to elucidate the increased frequency of the DD genotype and $\mathrm{D}$ allele of $\mathrm{CAD}$ patients, to discover the effects of risk factors on the onset of $\mathrm{CAD}$, and to understand the mechanism behind the suggested protective role of the I allele against CAD.

\section{REFERENCES}

Abbud ZA, Wilson AC, Cosgrove NM and Kostis JB (1998). Angiotensin-converting enzyme gene polymorphism in systemic hypertension. Am. J. Cardiol. 81: 244-246.

Acartürk E, Attila G, Bozkurt A, Akpinar O, et al. (2005). Insertion/deletion polymorphism of the angiotensin converting enzyme gene in coronary artery disease in southern Turkey. J. Biochem. Mol. Biol. 38: 486-490.

Alvarez R, Reguero JR, Batalla A, Iglesias-Cubero G, et al. (1998). Angiotensin-converting enzyme and angiotensin II receptor 1 polymorphisms: association with early coronary disease. Cardiovasc. Res. 40: 375-379.

Beohar N, Damaraju S, Prather A, Yu QT, et al. (1995). Angiotensin-I converting enzyme genotype DD is a risk factor for coronary artery disease. J. Investig. Med. 43: 275-280.

Butler R, Morris AD, Burchell B and Struthers AD (1999). DD angiotensin-converting enzyme gene polymorphism is associated with endothelial dysfunction in normal humans. Hypertension 33: 1164-1168.

Cambien F, Costerousse O, Tiret L, Poirier O, et al. (1994). Plasma level and gene polymorphism of angiotensin-converting enzyme in relation to myocardial infarction. Circulation 90: 669-676.

Canavy I, Henry M, Morange PE, Tiret L, et al. (2000). Genetic polymorphisms and coronary artery disease in the south of France. Thromb. Haemost. 83: 212-216.

Costerousse O, Allegrini J, Lopez M and Alhenc-Gelas F (1993). Angiotensin I-converting enzyme in human circulating mononuclear cells: genetic polymorphism of expression in T-lymphocytes. Biochem. J. 290 (Pt 1): 33-40.

Drexler H and Hornig B (1999). Endothelial dysfunction in human disease. J. Mol. Cell Cardiol. 31: 51-60.

Eleni S, Dimitrios K, Vaya P, Areti M, et al. (2008). Angiotensin-I converting enzyme gene and I/D polymorphism distribution in the Greek population and a comparison with other European populations. J. Genet. 87: 91-93. 
Erbs S, Möbius-Winkler S, Linke A, Adams V, et al. (2006). Both T-786C and G894T polymorphism of endothelial nitric oxide synthase affect in-vitro endothelium-dependent relaxation of internal mammary artery rings from patients with coronary artery disease. Eur. J. Cardiovasc. Prev. Rehabil. 13: 826-831.

Expert Panel on Detection, Evaluation and Treatment of High Blood Cholesterol in Adults (2001). Executive Summary of The Third Report of The National Cholesterol Education Program (NCEP) Expert Panel on Detection, Evaluation, And Treatment of High Blood Cholesterol In Adults (Adult Treatment Panel III). JAMA 285: 2486-2497.

Ferrieres J, Ruidavets JB, Fauvel J, Perret B, et al. (1999). Angiotensin I-converting enzyme gene polymorphism in a lowrisk European population for coronary artery disease. Atherosclerosis 142: 211-216.

Foy CA, Rice GI, Ossei-Gerning N, Mansfield MW, et al. (1997). Angiotensin-converting enzyme (ACE) gene polymorphisms in patients characterised by coronary angiography. Hum. Genet. 100: 420-425.

Gardemann A, Fink M, Stricker J, Nguyen QD, et al. (1998). ACE I/D gene polymorphism: presence of the ACE D allele increases the risk of coronary artery disease in younger individuals. Atherosclerosis 139: 153-159.

Graham I, Atar D, Borch-Johnsen K, Boysen G, et al. (2007). European guidelines on cardiovascular disease prevention in clinical practice: executive summary. Fourth Joint Task Force of the European Society of Cardiology and other societies on cardiovascular disease prevention in clinical practice (constituted by representatives of nine societies and by invited experts). Eur. J. Cardiovasc. Prev. Rehabil. 14 (Suppl 2): E1-40.

Harrap SB, Davidson HR, Connor JM, Soubrier F, et al. (1993). The angiotensin I converting enzyme gene and predisposition to high blood pressure. Hypertension 21: 455-460.

Hoshida S, Kato J, Nishino M, Egami Y, et al. (2001). Increased angiotensin-converting enzyme activity in coronary artery specimens from patients with acute coronary syndrome. Circulation 103: 630-633.

Hubert C, Houot AM, Corvol P and Soubrier F (1991). Structure of the angiotensin I-converting enzyme gene. Two alternate promoters correspond to evolutionary steps of a duplicated gene. J. Biol. Chem. 266: 15377-15383.

Istrati VF, Butorov IV, Manea DV, Ikim AA, et al. (2006). The incidence of some angiotensin-1 converting enzyme gene alleles in patients with coronary heart disease. Klin. Med. 84: 22-24.

Kogawa K, Nishizawa Y, Hosoi M, Kawagishi T, et al. (1997). Effect of polymorphism of apolipoprotein E and angiotensin-converting enzyme genes on arterial wall thickness. Diabetes 46: 682-687.

Lee YJ and Tsai JC (2002). ACE gene insertion/deletion polymorphism associated with 1998 World Health Organization definition of metabolic syndrome in Chinese type 2 diabetic patients. Diabetes Care 25: 1002-1008.

Li D, Singh RM, Liu L, Chen H, et al. (2003). Oxidized-LDL through LOX-1 increases the expression of angiotensin converting enzyme in human coronary artery endothelial cells. Cardiovasc. Res. 57: 238-243.

Mattu RK, Needham EW, Galton DJ, Frangos E, et al. (1995). A DNA variant at the angiotensin-converting enzyme gene locus associates with coronary artery disease in the Caerphilly Heart Study. Circulation 91: 270-274.

Nacak M, Davutoğlu V, Soydinç S, Dinckal H, et al. (2004). Association between angiotensin converting enzyme gene polymorphism and coronary artery disease in individuals of the South-Eastern Anatolian population. Anadolu. Kardiyol. Derg. 4: 45-51.

Nakai K, Itoh C, Miura Y, Hotta K, et al. (1994). Deletion polymorphism of the angiotensin I-converting enzyme gene is associated with serum ACE concentration and increased risk for CAD in the Japanese. Circulation 90: 2199-2202.

Niemiec P, Zak I and Wita K (2007). Modification of the coronary artery disease risk associated with the presence of traditional risk factors by insertion/deletion polymorphism of the ACE gene. Genet. Test 11:353-359.

Niemiec P, Zak I and Wita K (2008). The D allele of angiotensin I-converting enzyme gene insertion/deletion polymorphism is associated with the severity of atherosclerosis. Clin. Chem. Lab. Med. 46: 446-452.

Oren I, Brook JG, Gershoni-Baruch R, Kepten I, et al. (1999). The D allele of the angiotensin-converting enzyme gene contributes towards blood LDL-cholesterol levels and the presence of hypertension. Atherosclerosis 145: 267-271.

Pfohl M, Athanasiadis A, Koch M, Clemens P, et al. (1998). Insertion/deletion polymorphism of the angiotensin I-converting enzyme gene is associated with coronary artery plaque calcification as assessed by intravascular ultrasound. J. Am. Coll. Cardiol. 31: 987-991.

Pfohl M, Koch M, Prescod S, Haase KK, et al. (1999). Angiotensin I-converting enzyme gene polymorphism, coronary artery disease and myocardial infarction. An angiographically controlled study. Eur. Heart J. 20: 1318-1325.

Rigat B, Hubert C, Corvol P and Soubrier F (1992). PCR detection of the insertion/deletion polymorphism of the human angiotensin converting enzyme gene (DCP1) (dipeptidyl carboxypeptidase 1). Nucleic Acids Res. 20: 1433.

Sayed-Tabatabaei FA, Oostra BA, Isaacs A, van Duijn CM, et al. (2006). ACE polymorphisms. Circ. Res. 98: 1123-1133.

Seckin D, Ilhan N, Ilhan N and Ozbay Y (2006). The relationship between ACE insertion/deletion polymorphism and coronary artery disease with or without myocardial infarction. Clin. Biochem. 39: 50-54.

Settin A, Elbaz R, Abbas A, Abd-Al-Samad A, et al. (2009). Angiotensin-converting enzyme gene insertion/deletion polymorphism in Egyptian patients with myocardial infarction. J. Renin. Angiotensin. Aldosterone Syst. 10: 96-100.

Suzuki T, Yokota H, Yamazaki T, Kitamura K, et al. (1996). Angiotensin converting enzyme polymorphism is associated 
with severity of coronary heart disease and serum lipids (total cholesterol and triglycerides levels) in Japanese patients. Coron. Artery Dis. 7: 371-375.

Vaisi-Raygani A, Ghaneialvar H, Rahimi Z, Nomani H, et al. (2010). The angiotensin converting enzyme D allele is an independent risk factor for early onset coronary artery disease. Clin. Biochem. 43: 1189-1194.

van Berlo JH and Pinto YM (2003). Polymorphisms in the RAS and cardiac function. Int. J. Biochem. Cell Biol. 35: 932-943.

Vargas-Alarcón G, Zamora J, Sánchez-García S, Rodríguez-Pérez JM, et al. (2006). Angiotensin-I-converting enzyme (ACE) insertion/deletion polymorphism in Mexican patients with coronary artery disease. Association with the disease but not with lipid levels. Exp. Mol. Pathol. 81: 131-135.

Zhang S, Day I and Ye S (2001). Nicotine induced changes in gene expression by human coronary artery endothelial cells. Atherosclerosis 154: 277-283. 